\title{
South African Cinema (1)
}

By Martin P. Botha

Spring 2006 Issue of KINEMA

\section{YEARS OF SOUTH AFRICAN CINEMA (Part 1)}

The South African film industry is one of the oldest in the world. The Kinetoscope, invented by Thomas Edison, reached Johannesburg by 1895, only six years after its introduction in New York. Between 1895 and 1909 mainly British and American films reached many parts of South Africa by means of mobile bioscopes. The first permanent cinema was built in 1909 by Electric Theatres Limited in Durban. Over the next five years several film distribution companies built cinemas across the country, which led to serious competition.

By 1913, New York-born Isodore W. Schlesinger brought all film distributors under the control of his company, African Films. Although the first ever newsreels were filmed at the front during the Anglo-Boer War (18991902), African Films started a tradition of newsreel production in the form of The African Mirror, the world's longest-running newsreel (1913-1984). Forty-three films, some of them epic in scope, were also made between 1916 and 1922 by Schlesinger's company. These films included De Voortrekkers/ Winning a Continent (1916), Allan Quartermain (1919), King Solomon's Mines (1918), and Symbol of Sacrifice (1918). For the next 43 years Schlesinger had the monopoly of film distribution from the Cape to the Zambezi. By 1930 Schlesinger owned African Consolidated Theatres and African Consolidated Films after having temporarily lost control of distribution when sound films were introduced into South Africa. In 1930 African Consolidated Films founded the Killarney Film Studios in Johannesburg, which produced various films that were distributed in South Africa and overseas.

Sarie Marais, the first South African film with sound, was produced in 1931, after which local films gained in popularity. Sarie Marais as well as Moedertjie (1931) heralded the beginning of a decade in which Afrikaner (1) nationalism would grow in Afrikaans language films. In the 1930s Afrikaner nationalists established a film production organisation known as the Reddingsdaadbond Amateur Rolprent Organisasie (RARO), which, roughly translated, means "Rescue Action League Amateur Film Organisation". As an alternative film industry, RARO objected to the Anglo-American cultural imperialism prevailing in South Africa as a result of the showing of numerous overseas films.

Just as in the 1980's, when South Africans made alternative films to promote the struggle against the apartheid government (a resolution taken during the Culture and Resistance Conference in Gaborone in 1982), in the 1940s RARO saw its task as promoting Afrikaner nationalism. Its leader was Dr Hans Rompel. In 1939 RARO produced its first film, ' $n$ Nasie hou Koers. RARO films dealt with emotionally charged political events such as Dingaan's Day celebrations. During the 1940s, thus, Afrikaans language films in particular became politicised to promote Afrikaner nationalism. The Afrikaner nationalists also set up an alternative film distribution network entitled Volksbioskope-maatskappy. The aim was to distribute RARO films. Ironically, however (given Hans Rompel's attacks on American and British cultural imperialists) Volksbioskope-maatskappy was ultimately forced to distribute Hollywood studio films to stay solvent. When the National Party came into power in 1948 there was no further role for RARO and Volksbioskope, and both ventures stopped to exist.

South Africa also began to produce her own popular film actors and in the 1940s Al Debbo and Frederik Burgers in particular made a name for themselves in the film, Kom saam Vanaand (1949). Numerous local comedies in Afrikaans followed under the direction of Pierre de Wet such as Altyd in my Drome (1952), Fratse in die Vloot (1958) and Piet se Tante (1959). These films provided escapism to mainly white Afrikaans audiences. There were, however, Afrikaans language films, which also explored the identity of Afrikaner whites and their socio-political realities in more depth: Geboorteground (1946) examined the reality of poverty among Afrikaners during the era although in the form of social melodrama. Hans die Skipper (1953), in a visually elegant manner, explored the patriarchal nature of Afrikaner culture by telling the story of a conflict between father and son. These films were also the vehicles for many individuals who 
were later to become known as some of the acting pioneers in South African cinema, for example, Andre Huguenet, Wena Naude and many others.

In the 1950s Jamie Uys began to make a name as a director, first with Daar Doer in die Bosveld.(1951) Uys was basically producer, scriptwriter, director, photographer and lead actor in films such as Fifty-Vyftig (1953), Daar doer in die Stad (1954) and Geld soos Bossies (1955). Many of the Afrikaans language films of the 1940s and 1950s, although sometimes melodramatic or comedies, were covertly nationalist, enhancing the culture of an increasingly dominant Afrikaans influence in film.

The reality of South African filmmaking was that in many ways black South Africans were excluded. Black South Africans had no money to make films. They had no access to equipment. Opportunities were almost non-existent for black scriptwriters or directors to create their own images on the screen.

Schlesinger's African Films had a secure monopoly of the production of English language films till the late 1940s. Into this situation stepped Eric Rutherford and Donald Swanson, two Brits who had been working in southern Africa for the Rank Organisation of Britain. They were outsiders, people not brought up in the stifling racial atmosphere of South Africa. Their first film, African Jim (1949) became a landmark in South African cinema. Influenced by Italian Neorealism and post-war British cinema, it used ordinary black South Africans in everyday situations and in actual locations. It also celebrated the talent of black South Africans such as Dolly Rathebe on the screen, talents which were ignored by local filmmakers for decades up to the 1950s. Swanson's The Magic Garden (1951) is a classic chase story, a hunt for a thief and stolen money.

Attempts at socio-political filmmaking, which would include black South Africans, were represented by Zoltan Korda's Cry the Beloved Country (1951), which was based on the book by Alan Paton. The film depicts the social and economical degradation of black South Africans in a way never done before. The film introduced the talents of one of the pioneers of African cinema, Lionel Ngakane, who gave a superb performance in his first acting role. Ngakane, with no further prospects in South Africa after this film, left for the United Kingdom and went into exile until he was able to return to his home country in 1993. He became a founding member of Fédération Panafricaine de Cinéastes (FEPACI). Throughout his years in exile as a filmmaker Ngakane pursued his ultimate ambition of making films that would explain the inhuman conditions forced on his people by apartheid. He played a key part in drafting film policy for a post-apartheid South Africa and the establishment of the National Film and Video Foundation of South Africa, of which he was a council member from 1999 until 2002.

By the end of the 1950s and the first decade of the National Party Government most of the worst laws of mandatory separation had been passed - regulating education, sexual relationships, work, living space, in fact, virtually every area of human activity, on the basis of race. New York independent filmmaker, Lionel Rogosin's Come Back, Africa (1959), the first local film to be made covertly, tells the story of a black man, Zacharia, who becomes trapped in the classic South African situation: A migrant worker without skills looking for a job where he has no right to work. The film is a seminal work on the conditions of blacks under apartheid. (2)

By the 1950s Hollywood's Twentieth Century Fox decided to become directly involved in South Africa. In 1956 they bought out the Schlesinger empire. Between 1956 and 1969 Twentieth Century Fox controlled more than three-quarters of the South African film distribution network. One of the few independent film distributors outside the Twentieth Century Fox network was the Pretoria-based Wonderboom Inry Beleggings (WIB). WIB developed in Ster Film Imports, which was financed by the insurance company, Sanlam. During the 1960s Ster Films built three major film theatre complexes. By 1969 Sanlam bought out Twentieth Century Fox. This they merged with Ster Films to form Satbel, (the Suid-Afrikaanse Teaterbelange Beperk). At that stage Satbel controlled 76 percent of South Africa's distribution network. The other 24 percent was controlled by UIP-Warner. Afrikaner capital, thus, became a significant factor in the film industry when Sanlam acquired this major interest in Ster-films, a distribution company with the explicit intention to provide cinema predominantly for white Afrikaner patrons. By 1969 the financing, production and distribution of films in South Africa were now virtually in the hands of one large company.

Since 1956 and the introduction of a regulated subsidy system, the Nationalist government and big business collaborated to manipulate local filmmaking. Ideology and capital came together to create a national cinema 
that would reflect South Africa during the Verwoerdian regime of the 1960s. However, it was initially a cinema for whites only, and predominantly Afrikaans. Of the 60 films made between 1956 and 1962, 43 were in Afrikaans. Four were bilingual and the remaining 13 were English. This subsidy system only rewarded box-office success. Only when a film had earned a specific amount of money at the box-office did it qualify for the subsidy, which paid back a percentage of costs. This percentage was initially higher for Afrikaans language films than for English productions. It was therefore evident that the Verwoerdian government realised the potential influence this Afrikaner-dominated industry would have on the growth and spread of the Afrikaans language and to strengthen the dominant culture.

The white Afrikaans audience for this local cinema was relatively large and very stable, guaranteeing nearly every Afrikaans language film a long enough run to break even as long as it provided light entertainment, basically escapism, and dealt in an idealist way with Afrikaner reality and beliefs. It meant that Afrikaners wanted their ideals visualised in these films. This idealistic conservatism was characterised by an attachment to the past, to ideals of linguistic and racial purity and to religious and moral norms.

A few pioneers of the Afrikaans film industry of the sixties, however, produced a number of films that could be labelled "involved films". The theme of these films was an examination of the cracks in apartheid ideology. They included Emil Nofal-Jans Rautenbach films like Die Kandidaat (1968) and Katrina (1968). (3) In Die Kandidaat (The Candidate) Rautenbach examines various aspects of the urban Afrikaner through the events surrounding the election of a new director for the Adriaan Delport Foundation. As the backgrounds of the potential candidates have been thoroughly checked the appointment should be a mere formality. Instead the meeting degenerates into a bitter dispute over which one of the council members satisfies the requirements of genuine Afrikanerdom. Die Kandidaat explores the Afrikaner psyche critically and exposes the hypocrisy of those designated as "super" Afrikaners. Katrina is based on a powerful story by Basil Warner, Try for White. The film was, for its time, a shocking exposé of the horrors of apartheid and the racial classification system. It focuses on a "coloured" woman, Katrina, who "tries for white". She renounces her mother and father to make possible a better life for herself and her son in apartheid South Africa. Her son is unaware of his roots and is dating a white girl. A white Anglican priest falls in love with Katrina and their lives are shattered when the secrets are revealed. The film remains of the most innovative films to come out of the apartheid years of the sixties.

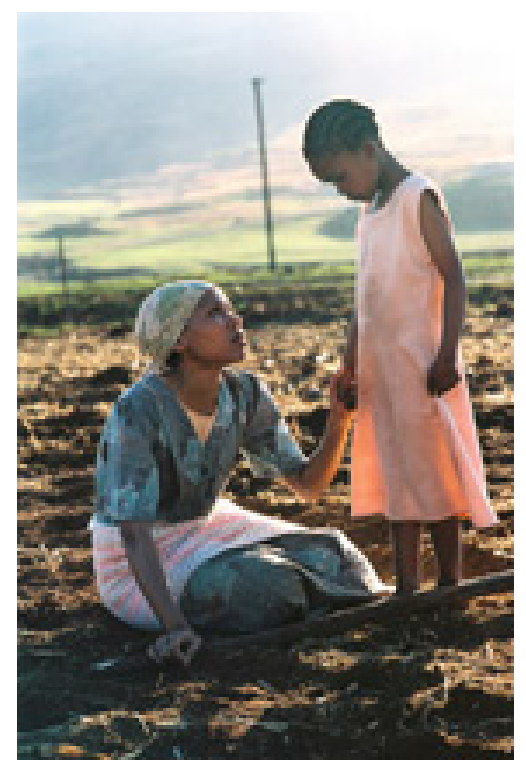

Figure 1: Yesterday by Darrell Roodt

Jans Rautenbach's Jannie Totsiens (1970) can be regarded as an expressionistic psychodrama and one of South Africa's few avant-garde films to date. Rautenbach uses a mental institution as an allegory of South African society under apartheid. The film caused a sensation, especially among the intellectuals of the 
time. However, South African audiences were not ready for this stimulating psychological drama, which has challenged Afrikanerdom's conservative culture. Even by today's standards it remains a fascinating portrait of a nation's confused psyche.

This "movement" came up against censorship and Afrikaner resistance, however, and could not succeed in making a real and lasting cultural contribution. The images of Afrikanerdom by Rautenbach in Jannie Totsiens, certainly did not meet the expectations of audiences. They rejected these films and rather flocked to those who portrayed them as chatty, heart-warming and lovable. Their conception of socio-political reality was confined to the conventions of Afrikaans soapies about mismatched couples, who had to overcome obstacles on the path to true love! Sadly, severe moral censorship prevented South Africans from viewing the international landmarks such as Fellini's Satyricon, Bertolucci's Last Tango in Paris and 1900, Pontecorvo's The Battle of Algiers and many other films, which at that critical stage would have challenged our conceptions of sexuality, politics, race and aesthetics.

The Afrikaans films of the 1960s and 1970s (with a few exceptions) ignored the socio-political turmoil of the period, as well as the realities experienced by black South Africans. Most Afrikaans language films communicated by means of obsolete symbols that had little multicultural communication value. They painted a one-sided and stereotypical portrait of the Afrikaner, leading to a misconception about who and what the Afrikaner was. Furthermore, the negative portrayal of blacks as a servant class in these films is a visual symbol of the deep-seated apartheid ideology. The exceptions were very few in the 1970s. Director Manie van Rensburg entered the field of Afrikaner culture through political satire. His film, Die Square, which made a notable satirical statement, was banned at first by the Publications Board.

One of the few directors, who enjoyed international recognition, was Jamie Uys. In 1975 Uys received the Golden Globe award for the best documentary film, Beautiful People, and followed this with another successful production, The Gods must be Crazy (1980). In his various films Uys nurtured his love of the wild, which became part of the iconography of his films, especially in Dirkie (1969), Beautiful People and The Gods Must Be Crazy, with their stunning images of the Kalahari Desert. While his earlier work explored in a humorous way the tensions between English and Afrikaans speaking whites (e.g. Lord Oom Piet), his later work were either widely applauded for their entertainment value or condemned for their ideological content. (4) After Jamie Uys's film, Funny People, which was based on Candid Camera, the theme was used and abused in the 1980s and 1990s, especially by comedian Leon Schuster.

Apart from Rautenbach and Van Rensburg, another outstanding South African filmmaker of the 1970s was Ross Devenish, who made three internationally praised films, Boesman and Lena, The Guest and Marigolds in August. Boesman and Lena (1973), based on Athol Fugard's play, was the first local feature to portray the poverty and enforced removal of South Africans classified as "black" under apartheid. The Guest (1977) focuses on a small period in the life of Afrikaner intellectual, poet, writer and opium addict, Eugene Marais, going "cold-turkey" on a farm, called Steenkampskraal. Athol Fugard plays Marais as he staggers inevitably towards suicide.

Devenish cuts incisively through the mythical stereotype of Marais, who believed that the existence of life is founded on pain and sorrow. This pain is the subject of a graceful, austere and controlled film, which handles its themes almost with musical skill. It is passed on and explored with almost a fugue-like pattern, from person to person, from voice to voice, until Marais' point seems irrefutable. Lastly, Marigolds in August (1979) portrays the tension between a poor, black man and an unemployed black man, who is struggling to support a family in a township near Port Elizabeth. The township is a place where malnutrition is rife. It is from this place that the one man walks every morning to work in the white beach resort. His security, however, is threatened by the presence of Melton, who is looking for work.

The third of Devenish's collaborations with Athol Fugard, the film was one of the few local features in the 1970s, which examined the conditions of blacks in South Africa. It became an international award winner at various film festivals, including Berlin. After struggling for almost a decade to make films in South Africa, Devenish left the country to work in England. Filmmakers such as Devenish and Rautenbach found it difficult to make the kind of film at home, which deals critically with socio-political issues. They have encountered problems with subsidy, the censors, distributors and the predominant white audiences. At this stage, black and white audiences were treated differently. The audiences were separated each with its own 
set of rules and operations, films and cinemas. Only by 1985 were cinemas in South Africa desegregated.

An attempt to create a black film industry under apartheid during the 1970s resulted in the making of a large number of shoddy films in ethnic languages that were screened in churches, schools and community and beer halls. It was contrary to government policy to allow black cinemas in the urban white areas, as this would concede the citizenship of urban blacks. The urbanization of blacks was portrayed in these films as uniformly negative and homeland life as more fitting.

Any film that managed to be made which in any way reflected the South African society in turmoil was banned by the state, such as How Long (1976) by Gibsen Kente and Nana Mahomo's Last Grave at Dimbaza, (1974), or received no distribution whatsoever, and thus did not qualify for any film subsidy. A true national film industry therefore did not emerge through the Afrikaans and made-for-blacks films. Directors such as Simon Sabela (U-Deliwe, 1975), tried to make more meaningful work within this system, but they were severely constrained by censorship and white dominance in the film industry.

In the early 1980s, film attendance dropped to its lowest level as a result of the popularity of television, which was introduced in 1976, and a scarcity of good South African films. David Bensusan's film, My Country My Hat (1983) was one of the few creative films that made an innovative contribution to socio-political satire. This very powerful film examines the paranoia of a white working class couple and their relationship with a black man, who struggles to get a passbook. They "illegally" employ this man as a gardener. The theme is not so much the accidental killing of a man who may or may not be a housebreaker, as the plight of a man who simply does not exist because he has no reference book in apartheid South Africa.

Since the late 1970s and the early 1980s a group of film and video producers and directors who were not affiliated to the established film companies in the mainstream film industry, made films and videos about the socio-political realities of the majority of South Africans. Some of these films were shown at local film festivals such as the Durban and Cape Town International Film Festivals, and from 1987 until 1994, the Weekly Mail Film Festival. Other venues included universities, church halls, trade union offices and the private homes of interested parties. Most of the films experienced censorship problems during the State of Emergency during the 1980s, and many were banned.

The films had small budgets and were either financed by the producers themselves, by progressive organisations such as the International Defence and Aid Fund for South Africa for a united, democratic, non-racial South Africa and overseas television stations. These films were chiefly the product of two groups that emerged jointly: a group of white university students opposed to apartheid, and black workers who yearned for a film or video form using indigenous imagery that would portray their reality in South Africa that would give them a voice and space in local films. Together with numerous documentaries, community videos and full-length films such as Mapantsula, short films and even animation work (by William Kentridge) marked the beginning of a new, critical South African cinema.

Initially this new cinema was based on audio-visual material that reflected the realities of the black majority of South Africa in their aspirations and struggle for a democratic society, but since the beginning of the 1990s other marginalised voices were added to these documentaries and short films, for example those of women, gays and lesbians, and even the homeless. It is from these films and videos that the symbols and iconography of a national South African film industry could be drawn, rather than from the diversions produced by the Afrikaans cinema of the 1960s and 1970s, or the made-for-blacks cinema of the 1970s. Most of the new critical local films, features or short films could be described as progressive film texts in the sense that the majority of them are consciously critical of racism, sexism or oppression. They dealt with the lives and struggle of the people in a developing country and were mostly allied with the liberation movements for a non-racial, non-sexist South Africa.

Some of these films (short, features and documentaries) also dealt with events which were conveniently left out in official South African history books or in a contemporary context in actuality programmes on national television under control of the Nationalist regime. Therefore, they became guardians of popular memory within the socio-political process in South Africa.

According to film historians 1986/1987 can be regarded as the turning point in the South African film industry. Only then did several feature films begin to critically examine the South African milieu, as well as 
apartheid and colonial history. The outstanding film academic Keyan Tomaselli calls this the new wave in the South African film industry. Martin Botha and Adri van Aswegen labelled it an alternative film revival, a cinema that gave voice to those who were previously marginalised by apartheid. The films touched on issues of black-white conflict and friendship (Jock of the Bushveld), the poor treatment of black farm workers by certain farmers (A Place of Weeping), the effects of the Namibian war on whites ( ' $n$ Wêreld sonder Grense), terrorism (City of Blood) and the trauma of racial conflict (Saturday Night at The Palace).

Approximately 944 features were made during the 1980s, as well as nearly 998 documentaries and several hundred short films and videos. ${ }^{(5)}$ Although most of the features were of mediocre value, at least 20 to 30 remarkable indigenous local feature films were made. They included Mapantsula (1988) a vivid portrayal of the State of Emergency in the late eighties; On the Wire (1989), about the psychological scars left by the war in Namibia and Angola; The Road to Mecca (1991) a film on the life of artist Helen Martins; Andrew Worsdale's Shotdown (1987), a political satire; the evocative Afrikaans dramas by director Katinka Heyns, with strong female characters - Fiela se Kind (1987), Die Storie van Klara Viljee (1991) and Paljas (1997); Jobman (1989), a strong anti-apartheid drama set in the years after Sharpeville; and Manie van Rensburg's critical portrayal of Afrikaner nationalism during the 1940s in The Fourth Reich (1990).

During the 1990s further developments within the local film industry stimulated the production especially of short films, a significant development in the growth of the local film industry. The pay-television station M-NET initiated a project entitled NEW DIRECTIONS to give talented first-time South African and other African filmmakers and scriptwriters a break into the film industry. By the end of the 1990s M-NET's MagicWorks has completed 20 short films and two features. This project is a showcase for new talent in this country, and has led to some outstanding short films such as Come See the Bioscope, Angel and Salvation. First-time directors and screenwriters, some of them female, black or "coloured", explored a diversity of themes.

Director Khalo Matabane and scriptwriter Mtutuzeli Matshoba, for example, created an award-winning comedy Chikin Biz'nis about the vibrant South African informal economic sector, which provides millions of unemployed urban South Africans with alternative livelihood. Russell Thompson and Patrick Shai explored South Africa's culture of violence respectively in The Pink Leather Chair and Stray Bullet, while directors Dumisani Phakathi and Tamsin McCarthy highlighted intimate relationships against the background of the new South African democracy respectively in An Old Wife's Tale and Cry Me A Baby. Relevant social problems such as drug abuse (Stimulation) and abortion (The Apology) were also explored in these M-NET short films.

Another important development was the historic democratic elections of 1994 . The year 1994 could also be regarded as a landmark for the South African film industry. A comprehensive study by the research institution, the Human Sciences Research Council (HSRC), into the restructuring of the entire South African film industry was completed and forwarded to the Department of Arts, Culture, Science and Technology . The report of 400 pages by Martin Botha and HSRC colleagues received widespread praise throughout the local film and television industry.

The HSRC research team recommended that state aid to the local film industry should be administered by a statutory body referred to as the South African Film and Video Foundation (SAFVF). Commercial viability should not be the sole criterion for government support of locally made films. All types of films, including short films, should benefit, and a developmental fund should be used to support first-time filmmakers from previously marginalised communities. A Government-appointed Task Group extensively used this report during 1995 to draft the White Paper regarding a post-apartheid film industry. The White Paper was completed by 1996 and the National Film and Video Foundation Bill was accepted by Parliament in 1997.

In March 1995, the old South African film subsidy system, which was based on box office returns, ceased to exist, and an interim film fund became in operation. Ten million rands were annually distributed among various projects, which included funding for short filmmaking. In 1998, for example, R110,000 was allocated to the development of short films and R1,010,000 for the actual production of short films. During 1999 the proposed National Film and Video Foundation (NFVF) was established to support the local film industry, including short filmmaking. 


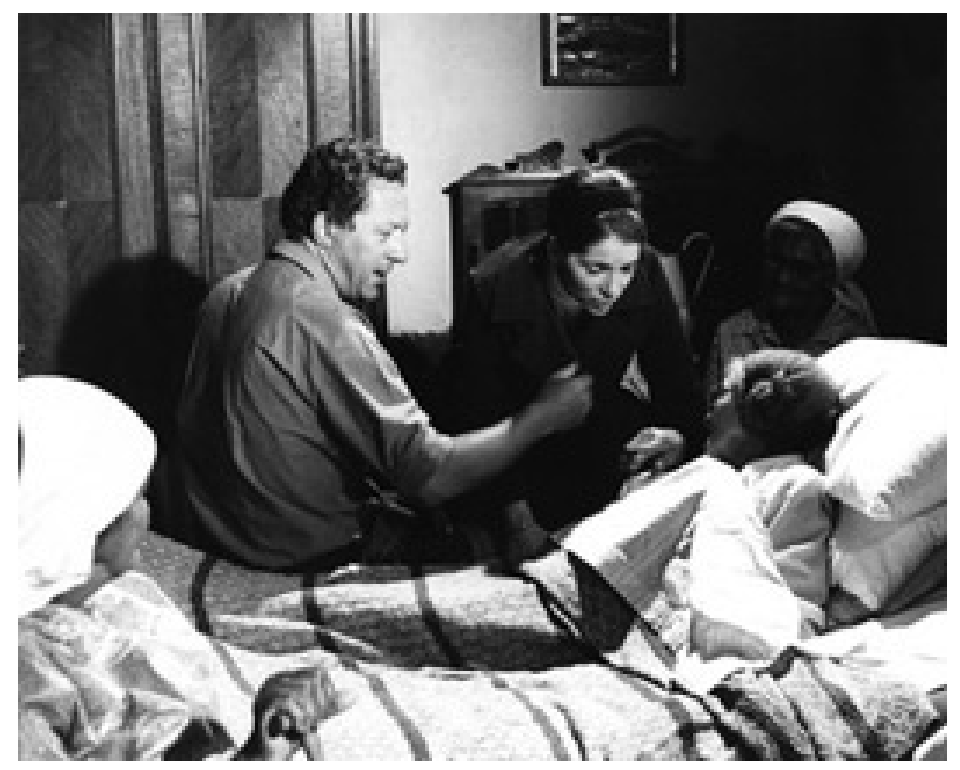

Figure 2: Director Jans Rautenbach and Jill Kirkland in Katrina

Regional initiatives further encouraged short film production. The Cape Film and Video Foundation and the South African Scriptwriters Association (SASWA) in collaboration with the Department of Arts, Culture, Science and Technology funded three short films, entitled Kap an Driver, a beautiful exploration of racial relations in the "new" South Africa; On the Rocks, about an affluent white man's encounter with Cape Town's homeless people; and Stompie and the Red Tide, also about Cape Town's homeless. The Southern African International Film and Television Market (Sithengi), (6) held every November in Cape Town, has become an important forum for locally made features and short films.

The year 1998 highlighted an important Pan-African short film initiative, called African Dreaming. The array of six short films is a major co-production, the first of its kind on the continent, which draws on talent from Mozambique, Namibia, Senegal, Tunisia, Zimbabwe and South Africa. International funding came from the South African Broadcasting Corporation (SABC), the Hubert Bals Fund in the Netherlands, Cable channel La Sept/Arte in France, YLE TV2 in Finland, HIVOS and NCDO in Holland, the CNC in France, the French Ministry of co-operation and Video Lab in South Africa. Deals and contracts were co-ordinated by one of South Africa's producers, Jeremy Nathan, through his company Catalyst Films. The South African film, Mamlambo, a love story between a black boy and a Chinese girl, gave first-time female and black director, Palesa Letlaka-Nkosi a chance to direct a fiction film.

Since the collapse of apartheid it became important for South Africa to establish partnerships with other film industries. Co-production treaties were signed with Canada, Italy and Germany, and others (e.g. the UK) are on the cards. Also notable are memoranda of understanding with countries such as India and Sweden, as well as South African industry players such as M-Net and the Media, Advertising, Publishing, Printing and Packaging Sector Education and Training Authority (MAPPP-SETA).

Post-apartheid cinema is characterized by the emergence of new voices and a diversification of themes. One thinks of a new generation of filmmakers such as Zola Maseko (The Life and Times of Sara Baartman, Drum), Ntshavheni Wa Luruli (Chikin Biznis - The Whole Story, The Wooden Camera), Akin Omotoso (God is African), Teboho Mahlatsi (Portrait of a Young Man Drowning), Dumisani Phakhati (Christmas with Granny, Waiting for Valdez), Ramadan Suleman (Fools, Zulu love letter), Sechaba Morojele (Ubuntu's Wounds), Gavin Hood (A Reasonable Man, Tsotsi), Zulfah Otto Sallies (Raya), Riaan Hendricks (A Fisherman's Tale), Khalo Matabane (Chikin Biz'nis), Jason Xenopoulos (Promised Land), Madoda Ncayiyana (The Sky in Her Eyes) and Norman Maake (Soldiers of the Rock, Homecoming).

For the first time South African audiences are exposed to certain marginalized communities, such as the 
homeless in Francois Verster's remarkable documentary Pavement Aristocrats: The Bergies of Cape Town (1998), the Himbas of Kaokoland in Craig Matthew's Ochre and Water (2001), AIDS victims in Shouting Silent (2001), the gay subcultures of the fifties and sixties in The Man Who Drove With Mandela (1998) and the San [Bushmen - editor's note] in the Foster Brothers' visual poem The Great Dance, (1999).

Ironically only a very few directors in the M-NET series moved on to features: Ken Kaplan (The Children and I) directed the award-winning black comedy, Pure Blood (2001); Russell Thompson (The Pink Leather Chair) made the gangster movie, The Sexy Girls (1998), and Zola Maseko (A Drink in the Passage) directed Drum (2004).

An important milestone in feature filmmaking is Jack Lewis's Proteus (2003), the beginning of a visible gay/lesbian cinema in South Africa. Under apartheid gay and lesbian voices in film and television were also silenced. In a seven year study of the depiction of gays and lesbians in African, Asian and Latin American cinema Martin Botha ${ }^{(7)}$ has noted that homosexual experience is unique in South Africa, precisely because of our history of racial division and subsequent resistance. Our gay identities have been formed by a long history of racial struggle. Our gay identities were also deformed by an oppressive system, which classified us into those with freedom and those without. Apartheid legislated whom we were, where we could live, with whom we could associate, and even what kind of sex we could have. Asserting a lesbian and gay identity in South Africa became a defiance of the fixed identities - of race, ethnicity, class, gender and sexuality - that the apartheid system attempted to imposture upon all of us. (8)

These notions are articulated in Proteus. Based on a true story, it is a period film that raises issues still of enormous relevance today. Historian and filmmaker Jack Lewis was fascinated by a court record in the Cape Archives, dated 18 August 1735, giving judgement in the case of two Robben Island prisoners. Dutch sailor Rijkhaart Jacobsz and Khoe convict Class Blank received extreme sentences for what the court called 'the abominable and unnatural crime of Sodomy'.

It is an extremely moving experience and forms part of a very small number of South African productions on homosexuality. Despite a new constitution which prohibits discrimination against gays and lesbians, as well as a strong gay movement, our images of gay men and women are limited and still on the margin of the film industry. One ends up with less than fifteen short films, a few documentaries, less than five features with openly gay and lesbian characters and virtually no television programmes during the past hundred years of South African cinema!

Another important theme in post-apartheid cinema is how South Africans are dealing with the traumatic past and how they are adjusting to the dramatic socio-political changes in contemporary South African society. Ubuntu's Wounds (2002) is a landmark in post-apart heid cinema. While several local documentaries have dealt with the Truth and Reconciliation Commission, Sechaba Morojele's film was the first attempt outside documentary filmmaking to examine the effectiveness of the process and it questions whether real forgiveness is possible in response to truly inhuman acts. And it is a considerable achievement to raise and examine these questions in less than 35 minutes. The film also shows off Morojele as an actor's director, eliciting strong performances from his ensemble cast.

Zola Maseko's moving A Drink in the Passage (2002) is a powerful short film about a touching encounter between a white and black man in South Africa during the 1960s. A celebrated black sculptor recalls the curious events, which led him to share a drink of brandy with a white family during the height of apartheid. It is a complex contemplation on the personal dimensions of enforced segregation and the power of art to transcend the divide. The criminal past and leaving it behind is the theme of Zulfah Otto-Sallies's Raya (2000), a story of three generations of women, their struggles and reconciliations. It is a visually beautiful insight into a closed, conservative community not often reflected on our screens.

Some of the most interesting features deal with the response of the Afrikaner community to the new democratic South Africa. One of the most powerful features since 1994 deals with an estranged Afrikaner community of white supremacists. In stark (almost black and white images) Promised Land (2003) depicts a desperate minority who, trying to retain their apartheid ideologies in the face of a new, democratic South Africa, have retreated into self-inflicted isolation and marginalization. When one saw Promised Land for the first time, one realizes again that there has been a bifurcation within Afrikaner culture. There is a clear split 


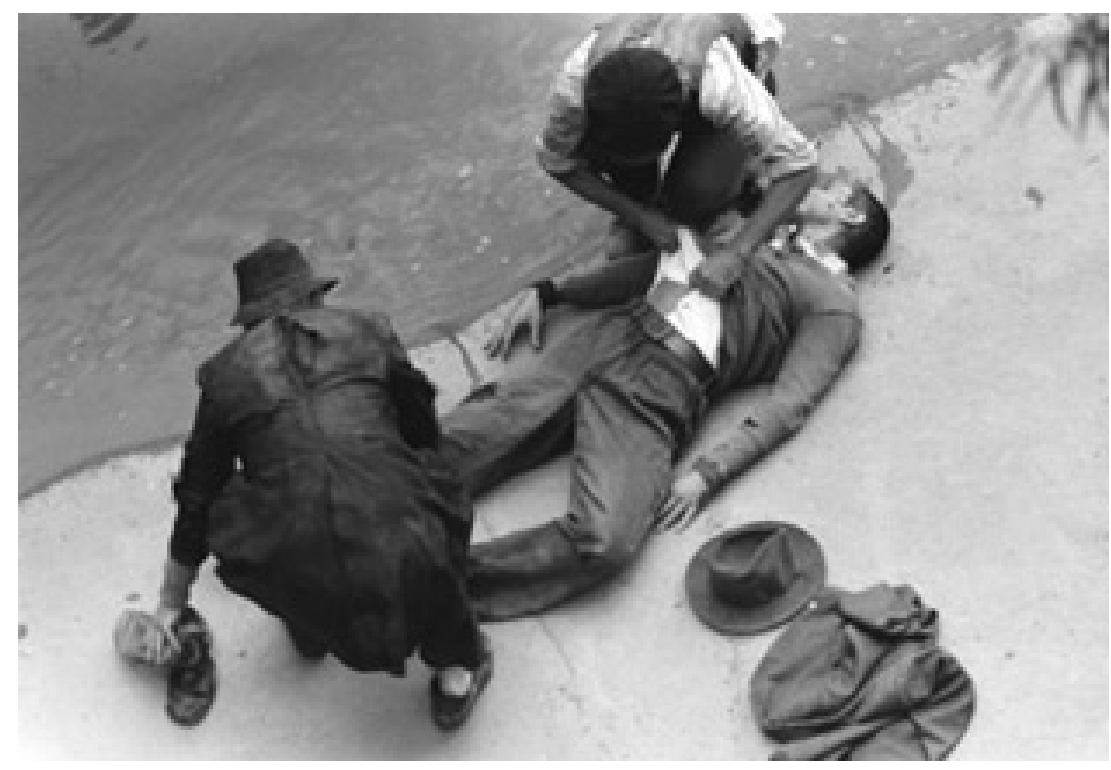

Figure 3: Jobman (dir. Darrell Roodt)

between the "old" and the "new".

Contemporary Afrikaners have been forced to make a choice after 1994. To choose between racial separation and assimilation and to acknowledge all the ideological ramifications that comes with that decision. Promised Land depicts both sides of this equation. It portrays the death of one era and the birth of another. In doing so Promised Land depicts the advocates of separatist ideology quite cruelly. With the same expressionist flair Ken Kaplan uses black comedy and the horror genre in Pure Blood to look at a group of white supremacists, who are trying to revive the old order of the apartheid years. The images of Afrikaners in Pure Blood and Promised Land are an important alternative to the idealised portrait of Afrikaners in the Afrikaans cinema of the 1970s.

Post-apartheid features are also dealing overwhelmingly and by necessity with the lives of Black South Africans. Two examples are Chikin Biznis - The Whole Story and Hijack Stories. Chikin Biznis, an internationally acclaimed film (Best Film at the Montreal Film Festival and Best Screenplay at the Festival Panafricain du Cinéma et de la Télévision de Ouagadougou (FESPACO, 1999), follows the fortunes and blunders of middle aged Sipho, who gives up his menial work at a Stock Exchange listed company to embark on a new venture: The lucrative trade of chicken business. Sipho not only faces stiff competition from others in this informal sector, but he has to deal with his family as well. Fats Bookholane deservedly won as Best Actor at FESPACO 1999. Surviving in the "informal sector", but in this case, in a milieu of crime, is also one of the themes of Oliver Schmitz's Hijack Stories. Completed in 2000 it took three years to get a theatrical release in South Africa, a fate faced by several of the post-apartheid features.

Ten years after South Africa has become a democracy our feature and documentary film industry is blossoming and receiving attention on the international stage. At various international film festivals during 2003 and 2004, including FESPACO, Rotterdam, Berlin, Cannes, Genova, Zanzibar and the Commonwealth Film Festival, retrospectives of South African cinema were held. The present is indeed an exciting time for South African features, documentaries and shorts. The South African Government and local government in regions such as Gauteng, KwaZulu Natal and the Western Cape have been quick to realise that the film industry offers this country huge earning potential and the creation of jobs. The government's national funding institution, the Industrial Development Corporation (IDC) has a fund of R250 million per annum earmarked for the film industry within South Africa. The IDC provides financial assistance by means of loans. Parallel with this, the South African Department of Arts and Culture and the National Film and Video Foundation (NFVF) have made grants to a total of 60 million Rand available to filmmakers during the past few years. The NFVF has been able to co-fund the production of more than ten feature films, most 
of which were submitted to the Cannes Film Festival in 2004.

During the past 18 months South African features, documentaries and shorts have won over 30 international awards, including the Oscar Nomination for Best Foreign Language film for Darrell Roodt's Yesterday. By dealing with marginalized voices Yesterday is a milestone in post-apartheid cinema. Directed by Darrell Roodt and arguably his best film since Jobman, Yesterday is the simple story of a young mother, who lives in rural KwaZulu-Natal with her pre-school child. Her migrant labourer husband works on the mines in Johannesburg. The woman takes ill, and after many attempts to visit a local clinic, learns that she is HIV positive. As a masterpiece of understatement Roodt and producer Anant Singh movingly highlights the difficulties that impoverished rural people who have AIDS encounter and the devastating effects of social stigma.

At the $55^{\text {th }}$ Berlinale Mark Dornford-May's U-Carmen eKayelitsha (Carmen in Khayelitsha), an adaptation of Georges Bizet's opera set in the Cape Town township of Khayelitsha and sung in Xhosa, was a surprise winner of the Golden Bear. The production was originally intended for the stage by the talented company Dimpho Di Kopane. By transferring the larger-than-life characters and their torments to a township milieu and a set of shacks at the Spier Estate near Cape Town, director Dornford-May tries to integrate the documentary-style of shooting with the stylized nature of opera. Unfortunately the characterization is not always convincing and the acting overall is sometimes mediocre. The best quality of the production lies with Giullio Biccari's mobile and inquisitive camera work.

A few weeks after the triumph at the Berlinale, South African cinema struck further gold at FESPACO. Zola Maseko's Drum, a visually stunning chronicle of South Africa during the 1950s, won the Golden Stallion. Drum depicts life in Sophiatown before the apartheid government bulldozed the beacon of non-racialism by the end of the fifties. It tells the story of Henry Nxumalo, a reporter of Drum magazine, and his reportage on the slave camps at Bethal Farm. American Taye Diggs gives a fine central performance as the investigative reporter, but the script of the film lets it down with clichés and anachronisms. Local critics questioned the film's claims to historical authenticity and ultimately the best thing about Drum is its wonderful art direction, which deservedly won the Prix du Meilleur Décor at FESPACO as well. Despite the mixed critical response to Maseko's first feature film, it won several more awards - A Silver Dhow, as well as the FIPRESCI Prize at Zanzibar 2005, and the Best South African Feature Award at the $26^{\text {th }}$ Durban International Film Festival.

Two other South African features triumphed at FESPACO as well. Ramadan Suleman's multi-award winning drama Zulu Love Letter won several awards, including the Best Actress Award for Pamela Monvete Marimbe. The film is set in a democratic South Africa where some wounds are left unhealed. Tormented by the haunting images and grief of our apartheid past, single mother and journalist Thandi (played by Monvete Marimbe) has difficulty communicating with her estranged daughter, Mangi. The thirteen-year-old child is deaf and dumb due to the beating that the pregnant Thandi received at the same time her friends were murdered by an apartheid hit squad. Suleman's film offers some potent drama, but ultimately the film fails because it raises too many issues without dealing with all of them adequately and thus becomes quite muddled.

Far more satisfying on a narrative and aesthetical level is first-time director Teddy Mattera's Max and Mona, which won the Prix Oumarou Ganda at FESPACO, as well as Best South African feature at the Apollo Film festival in 2005. It is one of the few black comedies to emerge out of South African cinema and is a wonderful treat; a perfectly balanced combination of grief, love and death. The principal character, Max, is treasured by his village, since he has inherited an extraordinary gift as a professional mourner. Inciting the ancestors, Max can reduce the stoniest heart to a flood of tears. He must, however, follow his calling to study medicine in the big city of Johannesburg. When in the city, Max realises that he cannot pay his study fees in time, and on top of this, he is saddled with a complaining sacred goat, called Mona. Max tries to get money from his Uncle Norman. Norman agrees only if Max is using his god-given talents for his financial redemption at various city funerals. Mattera and his co-writer Greg Latter deservedly won the Best Screenplay Award at the 2004 Cape Town World Cinema Festival.

The most outstanding feature of 2005 is Gavin Hood's Tsotsi. Winner of the Audience Award at the 2005 Toronto International Film festival, Tsotsi also made history at the 2005 Edinburgh Film festival by becoming the first film in more than seven years to win both the Standard Life Audience Award for most popular film, 
and the Michael Powell Award for Best Film. Based on the only novel written by Athol Fugard, the film depicts the story of a young boy orphaned at the age of nine and forced to claw his way to adulthood alone in the sprawling townships of Johannesburg. In the violent world he inhabits, Tsotsi lives forever in the moment. An impromptu car jacking resulting in the accidental kidnapping of an infant, forces him to confront his own humanity. The film is an emotive and very powerful journey in which the central character learns to confront the demons of his past while also coming to terms with the reality of his own destiny. Tsotsi was submitted as South Africa's official entry in the foreign film category for the 2006 Academy Awards and on 5 March it became the first South African feature to win the Oscar.

Thanks to digital technology the post-apartheid cinema is currently enjoying a revival. But the industry also faces major challenges. Despite the establishment of the NFVF and significant positive initiatives such as the Film Resource Unit to develop audiences for South African films, local filmmakers are still struggling, almost three decades after Ross Devenish's attempts, to find an audience for their work. The poor local performance of internationally acclaimed films such as A Reasonable Man, Chikin Biznis - The Whole Story, and Hijack Stories leaves one of with a feeling of déjà vu.

A film industry or in more ambitious terms, a national cinema, is ultimately dependent on the number of people who are willing to pay for it. Without a paying audience, whether it is cinema, television, video or new media exhibition, there can be no industry to speak of. With a total population of approximately 42 million people South Africa has a tiny cinema-going audience measured at approximately 5 million persons with a rapidly growing television consuming public penetrating approximately 49 percent of the total number of South African households.

In the future audience development will become more and more crucial for the post-apartheid cinema. Our film industry has been held to ransom for decades by the developed markets' funding and exhibition models, content and distribution strengths and world-wide dominance of the Hollywood studios. It has been estimated that Hollywood product dominates 99 percent of screen time in South African cinemas. Local filmmakers have to compete with films by independent American, British and Australian filmmakers, as well as "arthouse" films from Europe, the Middle East and Asia for the remaining one percent.

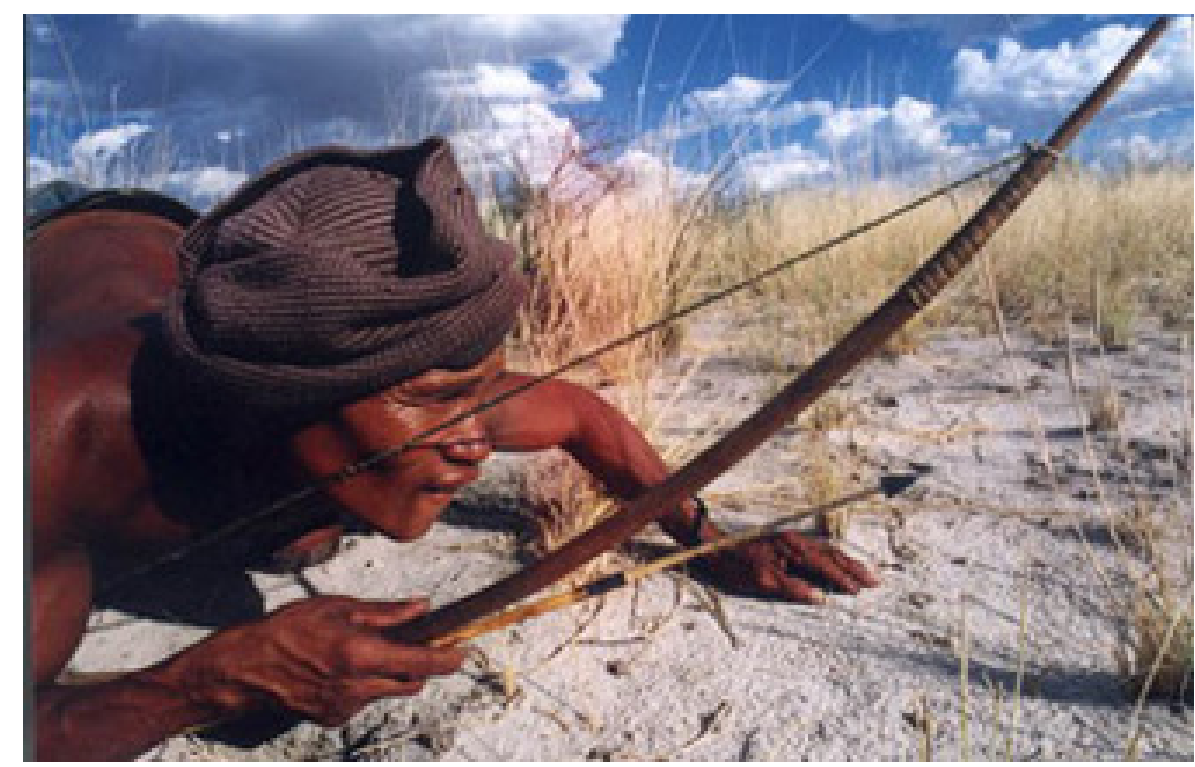

Figure 4: The Great Dance

Other challenges facing our industry are the inaccessible film exhibition sites that are outside the reach of the majority of South Africans, the limited concentration of theatres in metropolitan areas and the general lack of culturally specific, community based film exhibition points and product. According to recent research, audience attendance at South African cinemas is decreasing at an alarming rate to the extent that exhibitors have had to close down cinemas, especially in townships. Some independent cinemas in townships have 
been converted to churches. Various factors contribute to this decline, including the increase in the range of entertainment media, especially a wider range of television content, door price increases, unemployment, crime, and a lack of effective marketing strategies.

Some theatrical distributors such as UIP (United International Pictures) owned by international studios merely serve as a "courier service" between the international studios and the local exhibitors. They do not have a quota system for local content distribution and exhibition and the rationale that informs their decision to acquire and to exhibit or NOT to acquire and exhibit a product is based on its commercial viability. Criteria used to determine viability is sometimes out of touch with South African and African realities, especially if one studies the cultural role of cinema within African communities. The unfair competition and massive marketing budgets of Hollywood studio backed film releases reduce the chances of South African boxoffice success at the cinema level. The introduction of incentivised screen quotas for domestic and African film theatrical releases thus becomes a necessary intervention.

Through audience development programmes South African distributors and exhibitors can ultimately create a demand for local content on the screen, video hire, video sell thru, pay TV, free TV and public broadcasters, both locally and internationally. There is a definite need for aggressive marketing of South African films in people's home communities and the generation of media enthusiasm around promotion of their own films. South African film journalists and critics are also to be encouraged to support local product.

It is a fragile industry, especially in the face of globalisation.

[Editor's note: Part 2 and 3 of this article will be published in Kinema Fall 2006.]

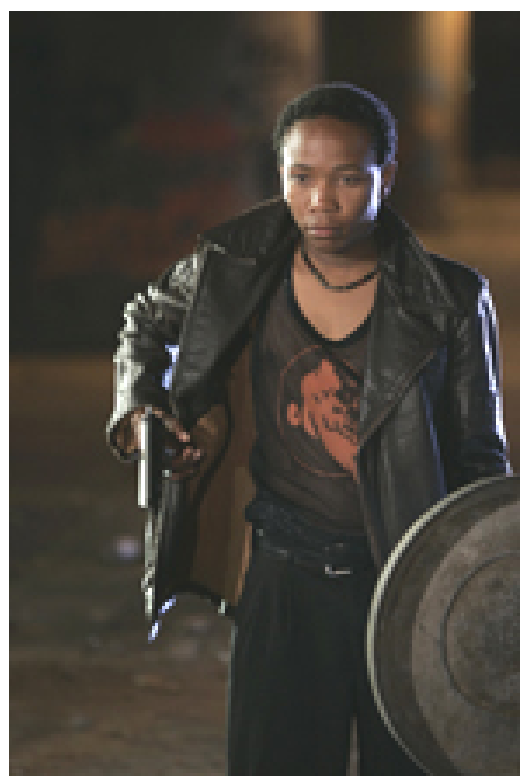

Figure 5: Presley Chweneyagae in Tsotsi

\section{Notes}

1. Afrikaners refer to the Afrikaans speaking white community in South Africa.

2. Peter Davis's publication on the making of Come Back Africa is a brilliant documentation of the problems faced by Rogosin to shoot the film in apartheid South Africa.

3. The work of Rautenbach is explored in depth in a new publication by Martin Botha, which will be 
launched on the 1st of October 2006.

4. See the ideological analysis of the films by Jamie Uys in Blignaut and Botha (1992).

5 . Some of these films were made due to tax breaks.

6. The name has now been changed to the Cape Town World Cinema Festival, which incorporates the market.

7. See Botha, MP. "Homosexuality and South African cinema." Kinema 19, (Spring 2003): 39-64.

8. See Gevisser, M. \& Cameron, E. 1994. Defiant desire: Gay and lesbian lives in South Africa. Johannesburg: Ravan.

\section{Author Information}

Martin P. BOTHA is Associate Professor of Film and Media Studies at the University of Cape Town. He has published more than 200 articles, reports and papers on South African media, including six books on South African cinema. His most recent book is South African Cinema 1896-2010 (Bristol: Intellect, 2012). 